\title{
Statyba
}

\section{THE DEVELOPMENT OF METHODS FOR RAPID PREDICTION OF FROST RESISTANCE OF CERAMIC PRODUCTS}

\section{A. Kičaitė}

To cite this article: A. Kičaite (1999) THE DEVELOPMENT OF METHODS FOR RAPID

PREDICTION OF FROST RESISTANCE OF CERAMIC PRODUCTS, Statyba, 5:3, 222-228, DOI:

10.1080/13921525.1999.10531466

To link to this article: https://doi.org/10.1080/13921525.1999.10531466

Published online: 26 Jul 2012.

Submit your article to this journal $₫$

Џ Article views: 44 


\section{KERAMINIŲ GAMINIŲ ATSPARUMO ŠALČIUI SPARČIŲJŲ PROGNOZAVIMO METODU RAIDA}

\section{A. Kičaitè}

\section{Ivadas}

Viena iš seniausiu dirbtinių statybiniu medžiagų yra keraminès plytos. Žinoma, kad šia statybinę medžiagą žmonès naudojo jau 3 tūkstantmetyje pr. $\mathrm{Kr}$. [1]. Yra daug pastatŭ, sumūrytu iš keraminiu plytu kurie stovi jau keletą anžiu nè kiek nenukentèję. Atidžiau pasižvalgę i pastatus, statytus pastaraisias dešimtmečiais, ju fasaduose neretai pastebime plytu suirimu. Tokias sienas jau reikia renovuoti, taigi labai aktualu, kad neatsparios šalčiui plytos nepakliūtu $i$ mūra.

Keraminiu plytų atsparumą šalčiui gana tiksliai galima nustatyti tiesioginiais šaldymo metodais. Šiuo metu paplitusius tiesioginius šaldymo metodus galima suskirstyti i dvi grupes pagal taikomas metodikas: 1) pagrisstas klasikiniu tūriniu bandinių šaldymu; 2) kurios remiasi vienpusio šaldymo principo taikymu.

Tūrinio šaldymo atveju vienu metu gali suirti visi keraminio bandinio paviršiai, bet tokiu suirimų realiomis salygomis nepastebime. Vienpusio šaldymo atveju paprastai suyra tik vienas paviršius ir geriau modeliuojamos natūinès sąlygos $[2,3]$.

Daugelio mokslininku nuomone, metodika, kuri remiasi tūriniu šaldymu, neleidžia ivvertinti faktinio keraminiu gaminių atsparumo šalčiui [4-7].

Šie tyrimai tiesioginiais šaldymo metodais užtrunka nuo keliu savaičiu iki keliu mènesių. Per toki ilgą laiką plytos atsiduria ne tik statybos aikštelèje, bet ir mūro sienoje. Todel vis svarbesnę reikšmę igyja spartieji prognozavimo metodai ir ypač tokie, kuriı rezultatai leidžia prognozuoti atsparumą šalčiui eksploatacijos salygomis.

\section{Keraminių gaminių atsparumo šalčiui sparčiuju prognozavimo metody skirstymas}

Keraminiu gaminių atsparumas šalčiui yra svarbi ir labai sudètinga jų savybè, priklausanti nuo išorinio eksploatacinio poveikio bei fizikiniu-cheminiu ir mechaninių keraminių gaminių savybių. Visas šias savybes lemia technologiniai faktoriai, ju gamybos parametrai.

Norint pagaminti atsparias šalčiui keramines plytas, reikia parinkti optimalią žaliavų sudétị ir tinkamiausią degimo proceso režimą $[2,3,8]$. Keraminiu gaminiu atsparumui šalčiui itakos turi aliumosilikatiniu žaliavy chemine ir mineralogine sudetis, formavimo ir džiovinimo salygos [2, 9]. Vokiečiu autorių duomenimis [10], visus faktorius, turinčius itakos atsparumo šalčiui rodikliui, galima suskirstyti $\mathfrak{i}$ dvi grupes priklausomai nuo:

1) žaliavos cheıninès, mineraloginès, granuliometrinès sudèties;

2) gamybos technologinių faktoriy (naudojamos irangos ir gamybos būdu).

Šie mokslininkai suskaičiuoja apie 50 ivairiu faktorių, kurie turi didesnès ar mažesnès itakos keraminiu gaminiu atsparumui šalčiui [10].

Akivaizdu, kad keraminių gaminiu atsparumo šalčiui problema yra sudetinga. Reikia analizuoti, tyrinèti ir surasti svarbiausius rodiklius, turinčius sąryši su atsparumu šalčiui. Šaldant įmirkytus vandeniu keraminius gaminius, atsiranda itempimai ir deformacijos, priklausantys nuo poru dydžio ir ju kiekio, isotinimo vandeniu koeficiento, pakilimo kapiliarais, rezerviniu ir pavojingu poru santykio, mechaninio atsparumo ir kt.

Sparčiaisias prognozavimo metodais tuo tiksliau galima numatyti keraminiu gaminių atsparumą šalčiui, kuo tiksliau ivvertintos medžiagu savybès, kurios šaldymo metu geriau parodo užšąlančio vandens ardomaji poveiki poringame kūne.

Dabartiniu metu keraminiu gaminiu atsparumo šalčiui sparčiuosius prognozavimo metodus galima skirstyti pagal prognozei naudojamų rodiklių kieki ir pagal nustatomas charakteristikas (žr. pav.). 
Spartieji keraminių gaminių atsparumo šalčiui prognozavimo metodai

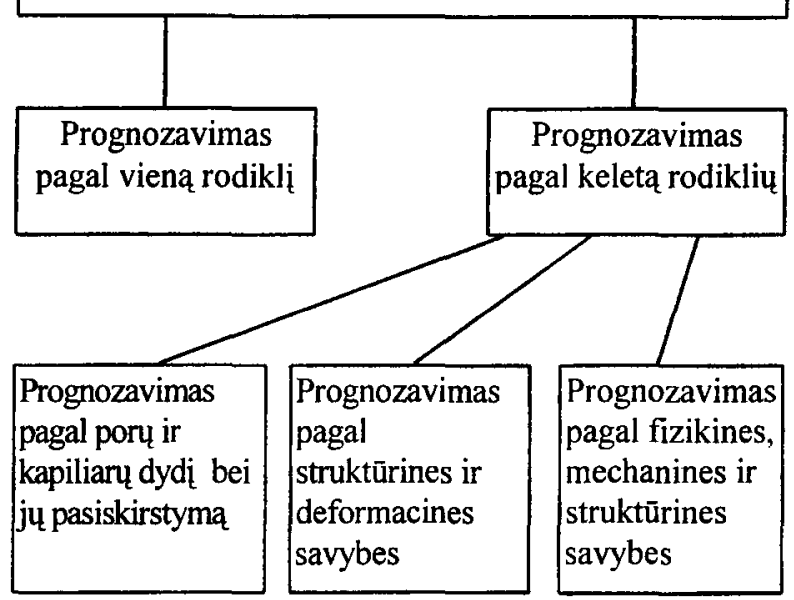

Keraminių gaminių atsparumo šalciui sparčiųiu prognozavimo metodų klasifikacijos schema

The scheme of classification of rapid prediction methods for frost resistance of ceramic products

Keraminiu gaminiu atsparumas šalčiui, nustatytas sparčiaisiais metodais, naudojant tiktai vieną rodiklį, pasirodè neobjektyvus (pvz., dideliu prognozavimo netikslumų buvo pastebèta, kai apie atsparumą šalčiui buvo sprendžiama tik pagal isotinimo vandeniu koeficientą [11, 12]).

Kaip matyti iš pav., objektyviausiai keraminių gaminiu atsparumą šalčiui galima prognozuoti metodais, ivertinanciais daugeli gaminio savybių:

1) pory ir kapiliary dydi bei ju pasiskirstyma;

2) struktūrinius ir deformacinius rodiklius;

3) fizikines, mechanines ir struktürines charakteristikas.

\section{Keraminiu gaminių atsparumo šalčiui progno-} zavimo pagal pory̨ ir kapiliary dydị bei pasiskirstymą analizé

Keraminiu gaminiu struktūra sudaryta iš kietosios fazès (kristalinès ir stiklo) ir tuštumy bei pory derinio. Keraminès šukès struktūra priklauso nuo kristalinès, stiklo, duju fazių fizikinès-cheminès prigimties bei kiekiu santykio ir pasiskirstymo visoje maseje [13]. Keraminiuose gaminiuose poros ir kapiliarai yra nevienodo skersmens, taigi vanduo užšąla skirtingose temperatürose. Pagal kapiliarinio vandens užšalimo dèsningumą: kuo mažesnis kapiliaro spindulys, tuo mažesnè jo užšalimo tikimybè, esant vienodai neigiamai temperatūrai $[12,14]$. Pavojingu itempimu ir deformaciju atsiradimo galimybe mažesnè palankios struktūros gaminiuose, kuriuose yra rezerviniu poru, sutei- kiančiu erdvę perteklinès drègmés migracijai $[2,3]$.

Mokslininkai pagal poru ir kapiliaru skersmeni bei ju kieki bando vertinti keraminiu gaminių atsparumą šalčiui. A. Ravaglioli [12] mano, kad, jei yra daugiau kaip $40 \%$ porı, kurių skersmuo mažesnis kaip $0,25 \mu \mathrm{m}$ ir $40-45 \%$ poru kuriy skersmuo didesnis kaip 1,4 $\mu \mathrm{m}$, tai toks keraminis gaminys bus atsparus šalciui. Jeigu dominuoja poros, kuriu skersmuo tarp 0,25 ir $1,4 \mu \mathrm{m}$, tai medžiaga bus neatspari salčiui.

A. S. Berkmanas ir I. G. Melnikova [14] atsparumą šalčiui vertina pagal rezervinių ir pavojingu pory kieki. Jų nuomone, poros, kurių spindulys didesnis negu $200 \mu \mathrm{m}$, yra rezervinès, nuo $200 \mu \mathrm{m}$ iki $0,1 \mu \mathrm{m}-$ pavojingos. Jei ju spindulys yra mažesnis kaip $0,1 \mu \mathrm{m}$, tai jos priskiriamos nepavojingoms.

M. Nakamura keraminiams gaminiams pavojingomis laiko poras, kuriu spindulys mažesnis kaip $0,1 \mu \mathrm{m}[15]$.

L. Franke, H. Bentrupas pateikia dar kitoki vertinima [16]. Jeigu keraminiame gaminyje poros, kuriu spindulys mažesnis kaip $0,60 \mu \mathrm{m}$, sudaro $50 \%$, tai jis neatsparus šalčiui ir priešingai - kai vidutinis porų spindulys yra didesnis kaip $1,65 \mu \mathrm{m}$, keraminis gaminys laikomas atsparus salciui.

M. Maage nustate [17], kad keraminiuose gaminiuose poros, kurių skersmuo mažesnis kaip $3 \mu \mathrm{m}$, pavojingesnès, negu poros, kurių skersmuo didesnis kaip $3 \mu \mathrm{m}$. Taikant statistinę analizę, buvo išvesta matematinè formulè:

$$
F=3,2 / P V+2,4 \times P 3,
$$

$F$ - apskaixiuotas atsparumas šalčiui; $P V$ užpildytu poru tūris; $P 3-$ porų $>3 \mu \mathrm{m}$ nuo visos $P V$ procentinè dalis. Keraminiu gaminiu atsparumas salčiui vertinamas taip, kai:

- $F>70$ - bandiniai yra atsparūs šalciui,

- F 55-70 - pereinama sritis,

- $F<55$ - bandiniai yra neatsparüs šalciui.

Dažniausiai poru dydžiai buvo nustatomi gyvsidabrio porometrijos metodu. Tokiems tyrimams imant 1-2 g bandinelius galima geriausiai ivertinti tiktai gaminio mikrostruktürą. Tačiau tada visai neatsižvelgiama i dideles poras ir defektus, darančius itaką dirbiniu eksploataciniam atsparumui salciui [18]. Mokslininku nustatytu pavojingu ir rezervinių porų skirtingumą galima paaiškinti nevienodomis keraminiu gaminiy atsparumo šalčiui nustatymo metodikomis. Vienos paremtos tūrinio, kitos - vienpusio šaldymo principais. 


\section{Keraminiy gaminį̣ atsparumo šalčiui prognozavimo pagal fizikines-mechanines ir struktūrines savybes raidos ivertinimas}

Prognozavimo pagal keletą fizikinių-mechaniniu charakteristiku metodui skirtas vokiečiu mokslininku darbas [19]. Cerpiu atsparumo šalčiui prognozei buvo išvesta lygtis:

$$
F S n=\frac{r^{0,17}}{T^{3} P^{2} \operatorname{tg} \alpha} \cdot \frac{\sigma_{\mathrm{zul}}}{\sqrt{E}} \cdot \frac{B}{D}
$$

FSn - atsparumo šalčiui skaičius, $r$ - vidutinis pory spindulys, $T$ - vakuumavimo büdu nustatytas imirkio koeficientas, $\sigma_{\text {zul }}-$ stiprumo koeficientas, nustatytas pagal stiprio tempiant ir lenkiant rodiklius, $P$ - bendrasis bandinio poringumas (nustatomas iš vandens imirkio duomeny vakuumavimo metodu), tg $\alpha-$ porų ir kapiliaru išsidèstymo pagal dydị integralinès kreivès užlinkimo kampas, $E$ - medžiagos tampros modulis, $B / D$ - santykis tarp čerpès paviršiaus ploto ir jos pločio (storio). Manoma, kad kai $F S n<11$, bandiniai esti neatsparūs šalčiui, 11-35 - pereinamojo pobūdžio, >35 - atsparūs šalčiui. Ši lygtis pritaikyta tik čerpiu atsparumui šalčiui prognozuoti.

Mokslininkai $[14,16]$ tyrè keraminiy gaminiu stiprumines charakteristikas (tokias kaip stipri tempiant, lenkiant, dinamini tampros moduli, ultragarso sklidimo greiti ir jo slopinimo koeficienta), bandydami nustatyti ju sąryši su atsparumo šalčiui rodikliu. Tokiu rodiklių ryšys su atsparumu šalčiui nebuvo stiprus, todèl tokie metodai nèra perspektyvūs.

Keraminiu gaminiu prognozavimo metodus kūré ir Lietuvos mokslininkai: A. Sadūnas, R. Mačiulaitis, R. Siaučiulis, A. Kaminskas, D. Būrè ir kt. Jie atliko nuodugnius tyrimus ir parengè nemaža sparčiuju prognozavimo metodų (žr. lent. [2, 3, 7, 20-35]).

Pirmieji metodai (3, 4 empirinés lygtys) buvo sukurti, nustačius koreliacini ryši tarp atsparumo šalčiui rodiklio ir struktūrinių bei stipruminį̣ charakteristiku [21-23]. Pats atsparumo šalčiui rodiklis buvo nustatomas türiniu būdu, tačiau vertinamas pagal charakteringus suirimus [20, 23].

Atliekant vẻlesnius tyrimus ( 5 ir 6 lygtys), keraminių gaminių atsparumas šalčiui tiesiogiai buvo nustatomas vienpusiu šaldymo metodu pagal GOST 7025-78 , p. 5 [36]. Toliau vienpusio šaldymo atveju vertinimo kriterijumi buvo pasirinkti keramikos gaminiu būdingi eksploatacijos sąlygomis paviršiniai suirimo požymiai. Tais metodais nustatytas koreliacinis ryšys tarp eksploatacinio atsparumo šalčiui ir struktūrinių bei stipruminiu charakteristiku $[3,24,25,31,34]$.

Tobulinant tiesioginị vienpusio šaldymo büdą buvo sukurta speciali patikimesnè šaldymo metodika [3, 25-31]. Ji taikyta ir nustatant koreliacini ryši tarp atsparumo šalčiui rodiklio (pagal specialią vienpusio šaldymo metodika) ir vien struktūrinių charakteristikų (7-10 empirinès lygtys).

Vieni spartieji metodai skirti tik vienos gamyklos keraminiams gaminiams (žr. 4, 6 empirines lygtis). Kiti metodai daug universalesni, tinkantys netgi kelioms gamykloms.

Universaliausi yra paskutiniai metodai (7-10 lygtys), nes jie buvo sukurti tiriant daugelio gamyklu gaminius, pagamintus skirtingose šalyse. Jais ivertinama ir suirimo dinamika.

Iš stipruminių ir struktūrinių rodikliu, kurie pateikiami auksčiau minètuose metoduose, dèsningu pokyčiu galima spręsti apie gamybos technologijos ita$\mathrm{ką} \mathrm{atsparumo} \mathrm{šalčiui} \mathrm{rodikliui}[3,34]$ :

- pagal struktūrinès charakteristikos ir dinaminio rezervo charakteristikos rodikliu pasikeitimus galima spręsti, ar gamybai naudojamas tinkamas mažo dispersiškumo molis;

- pagal struktūros nevienalytiškumo laipsnio, struktūros anizotropiškumo laipsnio ir medžiagos vienetinio tūrio suardymo smūgiais darbo rodikliu pasikeitimus galima ivertinti, ar gerai homogenizuota formavimo mase ir ar naudojama kiek galima mažesnio drègnumo masé;

- pagal medžiagos vienetinio tūrio suardymo smūgiais darbo, struktūros nevienalytiškumo laipsnio, struktūros anizotropiškumo laipsnio rodiklių pasikeitimus galima ivertinti džiovinimo režimo ypatumus;

- pagal isotinimo vandeniu koeficiento, vandens sugèrimo, atsparumo ribos lenkiant, vienetinio tūrio suardymo smūgiais darbo rodikliu pasikeitimus galima spręsti apie degimo kokybę ir pan.

Iš šių dèsningumų taip pat akivaizdu, kad keraminių gaminių atsparumui šalčiui turi jtakos ne vienas technologinis faktorius ir ne vienas parametras.

Pagal struktūrinius rodiklius prognozè užima ilgesni laiką (8-12 paru). Taikant kitus sparčiuosius keraminiu gaminių prognozavimo metodus atsparumą šalčiui galima ivertinti per $3-4$ dienas $[2,3,21,22$, 25, 33]. 
Keraminių plytı atsparumo šalčiui prognozavimo sparciaisiais metodais empirinès lygtys

Empirical equations for the methods for rapid forecast of ceramic brick resistance

\begin{tabular}{|c|c|c|}
\hline Prognozavimo rodikliai & Empirinè lygtis & Pastabos \\
\hline $\begin{array}{l}M \text {-atsparumas šalčiui (tūrinio } \\
\text { کaldymo ciklai) } \\
R_{\mathrm{f}} \text { - atsparumo riba lenkiant } \\
H \text { - kapiliarinio drèkinimo fronto } \\
\text { greitis } \\
A \text { - medžiagos vienetinio tūrio } \\
\text { suardymo smūgiais darbas } \\
q / H^{2} \text { - struktūros charakteristika } \\
\mathrm{e}-\text { natūrinio logaritmo pagrindas } \\
\mathrm{x}, \mathrm{y}, \mathrm{z}, \mathrm{d} \text { - laipsniu rodikliai }\end{array}$ & $\begin{array}{c}M=\mathrm{e}^{\mathrm{y}} \frac{R_{1}^{\mathrm{x}} A^{\mathrm{z}}}{\left(q / H^{2}\right)^{\mathrm{d}}} \\
\mathrm{R}=0,955, \mathrm{~S}= \pm 20 \%\end{array}$ & $\begin{array}{l}\text { Kelių gamyklu } \\
\text { produkcijai }\end{array}$ \\
\hline $\begin{array}{l}\text { Rodikliai tie patys, kaip ir } 3 \text { lygtyje } \\
t, y, z \text { - laipsniu rodikliai }\end{array}$ & $\begin{array}{l}M=k_{3} H^{\mathrm{t}} R_{\mathrm{l}}^{\mathrm{y}} A^{\mathrm{z}} \\
\quad \mathrm{R}=0,95, \mathrm{~S}= \pm 32 \%\end{array}$ & $\begin{array}{l}\text { Vienos } \\
\text { gamyklos } \\
\text { produkcijai }\end{array}$ \\
\hline $\begin{array}{l}M \text {-eksploatacinis atsparumas šaľiui } \\
A \text { - medžiagos vienetinio tūrio } \\
\text { suardymo smūgiais darbas } \\
q / H^{2}-\text { struktūros nevienalytiškumo } \\
\text { charakteristika } \\
\Delta H / H_{\text {vid }} \text { - struktüros koeficientas } \\
K_{\mathrm{H}} \text { - isotinimo vandeniu koeficientas }\end{array}$ & $\begin{array}{c}M=\mathrm{e}^{0,705} \frac{R_{1}^{0,727} A^{0,903}}{\left(q / H H^{2}\right)^{0,553}\left(\Delta H / H_{\mathrm{vid}}\right)^{0,839} K_{\mathrm{H}}^{10,561}} \\
\mathrm{R}=0,9797, \mathrm{~S}= \pm 20,24 \%\end{array}$ & $\begin{array}{l}\text { Keliu gamyklu } \\
\text { produkcijai }\end{array}$ \\
\hline $\begin{array}{l}h_{2}^{2} / g_{1}-\text { dinaminio rezervo } \\
\text { charakteristika } \\
C-\text { struktüros anizotropiškumo } \\
\text { charakteristika }\end{array}$ & $\begin{array}{c}M=5,9 \cdot 10^{7} \frac{\left(h_{2}^{2} / g_{1}\right)^{1,456}}{\left(q / h_{\min }^{2}\right)^{0,979} \cdot K_{\mathrm{H}}^{7,346} \cdot C^{1,840} W_{48}^{6,375}}(6) \\
\mathrm{R}=0,9916, \mathrm{~S}= \pm 20,87 \%\end{array}$ & $\begin{array}{l}\text { Vienos } \\
\text { gamyklos } \\
\text { produkcijai }\end{array}$ \\
\hline $\begin{array}{l}M_{1} \text { - eksploatacinis atsparumas } \\
\text { salčiui (pagal suirimo pradžią, kai } \\
W_{\ni} \leq 26 \% \text { ) } \\
P_{\mathrm{II}}-\text { poringos erdvès rezervas } \\
D \text { - salyginis porų ir kapiliarų } \\
\text { sieneliu storis } \\
N_{\mathrm{l}}-\text { struktūros nevienalytiškumo } \\
\text { laipsnis } \\
G_{1} \text { - kapiliarinio masès srauto greitis } \\
\text { vakuume šaldymo kryptimi } \\
G_{2} \text { - kapiliarinio masès srauto greitis } \\
\text { vakuume statmena jai kryptimi } \\
g_{2}-\text { kapiliarinio masès srauto greitis } \\
\text { šaldymo kryptimi } \\
W_{3}-\text { efektyvus poringumas }\end{array}$ & $\begin{array}{c}M_{1}=\mathrm{e}^{-1,464} \frac{P_{\Pi}^{1,068} D^{1,345} G_{1}^{0,275} G_{2}^{0,663}}{N_{\mathrm{h}}^{0,285} g_{2}^{0,830}} \\
\mathrm{R}=0,9377, \mathrm{~S}= \pm 37,43 \%\end{array}$ & $\begin{array}{l}\text { Ivairiu } \\
\text { gamyklu } \\
\text { produkcijai }\end{array}$ \\
\hline $\begin{array}{l}M_{2}-\text { eksploatacinis atsparumas } \\
\text { salčiui (pagal suirimo pabaiga, kai } \\
W_{3} \leq 26 \% \text { ) }\end{array}$ & $\begin{array}{r}M_{2}=\mathrm{e}^{-1,450} \frac{P_{\Pi}^{1,465} D^{0,759} G_{1}^{0,384} G_{2}^{0,852}}{N_{\mathrm{h}}^{0,168} g_{2}^{1,034}} \\
\mathrm{R}=0,9624, \mathrm{~S}= \pm 30,51 \%\end{array}$ & $\begin{array}{l}\text { lvairiu } \\
\text { gamyklu } \\
\text { produkcijai }\end{array}$ \\
\hline $\begin{array}{l}M_{1}-\text { eksploatacinis atsparumas } \\
\text { šalčiui (pagal suirimo pradžia, kai } \\
W_{3} \geq 26 \% \text { ) }\end{array}$ & $\begin{array}{r}M_{1}=\mathrm{e}^{-2,983} \frac{P_{\Pi}^{1,642} D^{2,332} G_{1}^{0,695} g_{2}^{0,779}}{N_{\mathrm{h}}^{0,334} G_{2}^{1,145}} \\
\mathrm{R}=0,9651, \mathrm{~S}= \pm 26,01 \%\end{array}$ & $\begin{array}{l}\text { Ivairių } \\
\text { gamyklu } \\
\text { produkcijai }\end{array}$ \\
\hline $\begin{array}{l}M_{2}-\text { eksploatacinis atsparumas } \\
\text { కalciui (pagal suirimo pabaiga, kai } \\
W_{3} \geq 26 \% \text { ) }\end{array}$ & $\begin{array}{c}M_{2}=\mathrm{e}^{-2,758} \frac{P_{\Gamma 1}^{1,813} D^{2,135} G_{1}^{0,178} g_{2}^{1,335}}{N_{\mathrm{h}}^{0,395} G_{2}^{0,517}} \\
\mathrm{R}=0,9753, \mathrm{~S}= \pm 22,65 \%\end{array}$ & $\begin{array}{l}\text { Ivairiu } \\
\text { gamyklu } \\
\text { produkcijai }\end{array}$ \\
\hline
\end{tabular}


5. Keraminiu gaminių atsparumo šalčiui prognozavimo metody pagal struktūrinius ir deformacinius rodiklius analizè

Užşąlant vandeniui keraminiame gaminyje atsiranda itempimai ir deformacijos. Deformacijos susijusios su keraminio gaminio atsparumu šalčiui.

R. B. Angenickaja [37] pagal išmatuotų linijinių deformaciju reikšmes apskaičiavo mechanines ittampas ir palygino jas su gaminiu atsparumo lenkimui rodikliais.

O. D. Paračenko kartu su kitais mokslininkais [38] naudojo kvarcini dilatometrą plyteliu ir kitu keraminių medžiagu sparčiajai atsparumo šalčiui prognozei. Metodas kalibruotas pagal tūrinio šaldymo rezultatus. Nustatyta, kad geriau išdegtos plytelès atlaiko daugiau šaldymo ciklų ir mažiau deformuojasi.

Buvo pastebètos didelès teigiamos deformacijos $[39,40]$ keraminiu gaminių, kurie pasižymejjo didesniu isotinimo vandeniu koeficientu $(0,9)$, turéjo tekstūros defektų ir buvo nepakankamai išdegti.

Minèti dilatometriniai metodai buvo tobulinami türinio saldymo pagrindu.

Vienpusio šaldymo principo taikymas dilatometriniams tyrimams, ypač modeliuojant eksploatacines klimatines sąlygas, atvèrè plačias galimybes keraminių gaminiu atsparumo šalčiui sparčiajai prognozei. Sparciajam eksploatacinio atsparumo šalčiui prognozavimui buvo sukonstruotas prietaisas DUM-1, kuriuo galima nustatyti daugeli deformacinių rodiklių $[2,3,41$, 42].

Žinoma empirine lygtis [41], kurioje taikomi tokie deformaciniai rodikliai:

$$
M=\mathrm{e}^{5,399-(325 \Delta H-1497 a-308 b+2 V g) \cdot 100},
$$

$\Delta H$ - gaminio paviršiaus sluoksnio deformacija per vieną cikla, $a, b$ - atitinkamai bendrosios ir liekamosios deformacijos (sluoksnyje) padidejimas per vieną cikla, $V g$ - deformacijos greitis.

11 lygties daugiamates koreliacijos koeficientas $\mathrm{R}=0,9600$, o paklaida $\mathrm{S}= \pm 22,80 \%$.

Vieno bandinio matavimo trukmè siekia $5 \mathrm{~h}$, nejskaitant imirkio vandeniu $48 \mathrm{~h}$. Prietaisu DUM tyrimai atliekami automatiškai.

Atlikus tolesnius tyrimus nustatyta [2], kad eksploatacinị atsparumą šalciui optimaliai aprašo lygtis:

$$
M=\exp \left(k_{\mathrm{o}}-k_{1} \Delta H_{1}-k_{2} K_{H}+k_{3} N\right),
$$

$\Delta H_{1}$ - gaminio paviršiaus sluoksnio deformacija per vieną cikla, $N$ - dinaminio rezervo rodiklis, $K_{\mathrm{H}}$ jotinimo vandeniu koeficientas.

12 lygties daugiamatès koreliacijos koeficientas $\mathrm{R}=0,993$, o paklaida $\mathrm{S}= \pm 5,52 \%$.

Ši lygtis taikoma keraminiams gaminiams, kuriu žaliavu sudètis ir gamybos technologijos panašios.

Pagal šiuos metodus (11 ir 12 lygtis) keraminių gaminị atsparumą šalčiui galima pakankamai operatyviai prognozuoti.

Perspektyvu šiuos metodus toliau tobulinti ir plètoti.

\section{Išvados}

1. Norint numatyti keraminiu gaminiu skirty pastatų sienoms ir konstrukcijoms, atsparumą šalciui, būtina prognozei taikyti vienpusiu šaldymu grindžiamus metodus.

2. Spartieji prognozavimo metodai, kai remiasi didesniu rodikliu skaičiumi, yra daug patikimesni ir geriau parodo keraminiu gaminiu atsparumą šalciui.

3. Spartieji prognozavimo metodai leidžia pakankamai greitai juertinti keraminiu gaminiu atsparuma šalčiui, juos taikant galima sustabdyti nekokybiškos produkcijos patekima i statyba.

4. Dilatometriniai metodai lengvai pritaikomi ir turi platesnio panaudojimo perspektyva.

\section{Literatūra}

1. Технология глиняного кирпича / ГІод ред. М. Н. Наумова. М.,1969. 43 c.

2. A. Sadūnas. Aliumosilikatinių dirbinių ilgaamžišksumas. Vilnius: VPU, 1997. $252 \mathrm{p}$.

3. Р. В. Мачюлайтис. Морозостойкость и долговечность изделий фасадной керамики. Вильнюс: Техника, 1997. $308 \mathrm{c}$.

4. B. Butterworth. Laboratory test and the durability of bricks. The recording comparison and use of outdoor exposure test // Trans. Brit. Ceram. Soc., 1964, Vol. 63. No 11, p. 615-628.

5. T. Ritchie, J. Davison. Moisture content and freezethaw cycles of mansory materials // Journ. Material., 1968, Vol. 13, No. 3, p. 658-671.

6. Ф. В. Ушков. Долговечность наружных отделочных слоев при одностороннем воздействии отрицательных температур // Сушка и увлажиение строительных материалов и конструкций: Сборник ВСНТО. М., 1957, c. 77-91.

7. А. С. Садунас, Р. А. Шяучюлис. Ускоренное определение морозостойкости керамического черепка // Строительные материалы, 1972, № 1, с. 31-33.

8. D. Hauck, E. Hilker, M. Ruppik. Einfluss der 
Feuerführung auf Frostwiderstandfähigkeit // Ziegelindustrie International, 1990, No 9, S. 501-507.

9. R. Šiaučiulis, A. Sadūnas, R. Giraitis. Granuliometrinès sudeties itaka keraminiu dirbiniu eksploataciniam atsparumui ડ̌alčiui // Statybinių medžiagu technologija: Konferencijos "Naujos statybinès medžiagos, konstrukcijos ir technologijos statyboje“, ivykusios Vilniuje $1991 \mathrm{~m}$. vasario 6-8 d., medžiaga. V: Technika, 1991, p. 3-6.

10. W. Bender, F. Händle. Frostwiderstandfähigkeit keramischer Baustoffe // Ziegelindustrie International, 1990, No 9, S. 467-469.

11. А. С. Садунас, Р. В. Мачюлайтис. А. П. Кичайте. Изменение величины коэффициента водонасыщения в процессе одностороннего замораживания-оттаивания // Рекомендации по ускорению научно-технического прогресса в производстве строительных материалов и изделий. Киев, 1987, с. 94-99.

12. A. Ravaglioli. 19 - Evalution of the frost resistance of pressed ceramic product based on the dimensional distribution of poures // Trans. and British. Ceram. Soc., 1976, Vol. 75, No 5, p. 92.

13. A. Balandis, V. Jasiukevičius, M. Martynaitis, K. Strazdas. Silikatu technologijos pagrindai. Vilnius: Moksio ir enciklopedijos 1-k]a, 1995. $438 \mathrm{p}$.

14. А. С. Беркман, И. Г. Мельникова. Структура и морозостойкость стеновых материалов. Л.: Госстройиздат, 1961. $166 \mathrm{c}$

15. M. Nakamura. Indirect Evalution of Frost Susceptibility of Building Materials // Am. Ceram. Soc. Bull. 1988, No 12, p. 1964-1965.

16. L. Franke, H. Bentrup. Beurteilung der Frostwiderstandfähigkeit von Ziegeln in Hinblick auf lange Lebensdauer // Ziegelindustrie International, 1993, No 9, S. 483-492.

17. M. Maage. Frostbeständigkeit und Porengrossenverteilung in Ziegeln // Ziegelindustrie International, 1990, No 9, S. $472-480$.

18. А. II. Кичайте, А. С. Садунас, Р. В. Мачюлайтис, Г. П. Станкявичюс. Особенности грубокерамических изделий высокой эксплуатационной морозостойкости // Материалы III республиканской конференции молодых ученых и специалистов ,Повышение эффективности в строительстве и промышленности сгроительных материалов“. Рига: РПИ, 1990, с. 19-20.

19. C. O. Pels Leusden. Zur Frostanspruchung von Dachziegeln // Joind. - Ztg., 1974, No 11, S. 291-294.

20. А. С. Садунас, Р. А. Шяуџюлис. Критерий морозостойкости. Морозостойкость как функция капиллярного радиуса // Сб. тр. ВНИИтеплоизоляция. Вып. 4. Вильнюс, 1970, с. 196-213.

21. Э.-А. В.-Л. Каминскас. Исследование экспресс-методов определения морозостойкости пористокапиллярного керамичсского тела пластического формования: Автореф. дис... канд. техн. наук. Вильнюс, 1974. 26 с.

22. Инструкция по скоростным методам определения морозостойкости строительного кирпича

// ВНИИтеплоизоляция. Вильнюс, 1974. 12 с.

23. А. С. Садунас, Р. А. Шяучюлис. Новая методика морозостойкости грубокерамического черепка пластического формования. Морозостойкость как фугкция структуры и прочности изделий // Сб. тр. ВНИИтеплоизолящия. Вып. 5. Вильнюс. 1971, с. 115-131.
24. А. С. Садунас, Р. В. Мачюлайтис. Прогнозирование эксплуатационной морозостойкости керамических материалов // Промышленность стеновых материалов, пористых заполнителей и местных вяжущих. М.: ВНИИЭСМ, 1989. 57 с.

25. Р. В. Мачюлайтис. Основы прогнозирования эксплуатационной морозостойкости изделий стеновой керамики. Вильнюс: ЛУГ, 1993. 39 с.

26. R. Maciulaitis. Frost resistance and long service life of ceramic facade products. Part 2 // Ziegelindustrie International, 1994, No 6, p. 419-428.

27. R. Maciulaitis. Frost resistance and long service life of ceramic facade products. Part 3 // Ziegelindustrie International, 1995, No 6, p. 423-440.

28. R. Maciulaitis. Frost resistance and long service life of ceramic facade products. Part $4 / /$ Ziegelindustrie International, 1995, No 7-8, p. 474-486.

29. R. Maciulaitis. Frost resistance and long service life of ceramic facade products. Part 5 // Ziegelindustrie International, 1997, No 7, p. 427-433.

30. А.с. 1588130 СССР, МКИ G $01 \mathrm{~N} 33 / 38$. Способ определения морозостойкости стеновых материалов / Р. В. Мачюлайтис, А. С. Салунас, В. А. Могутов, Ю. Д. Ясин, А. П. Кичайте, Г. П. Станкявичюс. № 44993171 23-33. Заявл. 19.09.88; Зарегистрировано в Госреестре 22.04.90. $5 \mathrm{c}$.

31. R. Mačiulaitis. Keraminès medžiagos atsparumo šalčiui artimose eksploatacinese salygose. 8. Naujas prognozavimo metodas // Priedy ir antrinil žaliavy panaudojimas statybinèse medžiagose: Darbł̨ rinkinys / Termoizoliacijos institutas. Vilnius, 1994, p. 102-110.

32. А. Садунас, Р. Мачюлайтис, Д. Буре. Долговечность строительной керамики. Вильнюс: ЛитНИИТИ, 1997. $36 \mathrm{c}$.

33. А. Садунас, Р. Мачюпайтис, А. Кичайте, Д. Буре. Комплексное решение оценки эксплуатационной морозостойкости грубокерамических изделий // 10. Internationale Baustoff- und Silikattagung: Tagungsbericht. Sekt. 3. Weimar, 1988, S. 202-207.

34. R. Mačiulaitis. Fasadinès keramikos atsparumas šalčiui ir ilgaamžiškumas. Vilnius: Technika, 1996. 132 p.

35. А. С. Садунас, Р. В. Мачюлайтис, А. П. Кичайте. Возможность прогнозирования эксплуатационной морозостойкости керамических изделий на основании ряда физико-механических свойств // Конференция молодых ученых химико-технологического факультета РГИ. Рига: РПИ, 1989, с. 118.

36. ГОСТ 7025-78. Материалы стеновые и облицовочные. Мстоды определения водонасыщения и морозостойкости.

37. Р. Б. Ангеницкая. Пуги повышения и методы испытания морозостойкости керамических строительных материалов // Труды совещания по морозостойкости керамических изделий. Рига, 1957, с. 81-100.

38. О. Д. Паращенко, К. А. Валешко, П. М. Гуденко, Д. Н. Квасницкая. Экспресс-метод определения морозостойкости керамических материалов. Реф. инф., серия „Промышленность стеновых материалов, пористых заполнителей и местных вяжущих". Вып. 3. М: ВНИИЭСМ, 1975. $37 \mathrm{c}$.

39. B. Butterworth, E. Carter. Laboratory test and durability of bricks. VIII. Frost dilatometry: modified methods // 
Trans. Brit. Ceram. Soc. 1967, Vol. 66, No 1, p. 1-12.

40. A. Watson. 42 - Laboratory test and durability of bricks VI: The mechanism of frost action on bricks // Trans. Brit. Ceram. Soc., 1964, Vol. 63, No 11, p. 663-680.

41. A. Sadunas, D. Bure, R. Matschjulaitis. Neue über Frosbeständigkeit der grobkeramischen Steinerzeugnisse // 12. Internationale Baustofftagung: Tagung bericht. Band 2. Weimar, 1994, S. 221-231.

42. Р. В. Мачюлайтис, Д. А. Буре. Комплексный контроль эксплуатационной морозостойкости стеновых керамических материалов // ЭО/ВНИИЭСМ. Сер. 4. Пром. керам. стеновых материалов и пористых заполнителей, 1990, № 2, с. 11-15.

Iteikta 19990615

\section{THE DEVELOPMENT OF METHODS FOR RAPID PREDICTION OF FROST RESISTANCE OF CERAMIC PRODUCTS}

\section{A. Kičaitè}

\section{S u $\mathrm{m} \mathrm{m}$ a r y}

One of important parameters determining the quality of ceramic products is the resistance to frost. Frost resistance of ceramic brick can be determined exactly by direct unilateral freezing methods. Investigations by these methods last from some days to several months. Therefore rapid prediction methods become more important.

Rapid methods for predicting frost resistance of ceramic products give more detailed data if chosen properties of materials that reflect better destructive action of water during freezing in a ceramic body are more exact.
Nowadays the methods for rapid prediction are divided according to the quantity of parameters used for prediction and according to the established characteristics. The prediction of frost resistance of ceramic products can be carried out using a parameter or some parameters. The prediction methods using some parameters are divided into three groups:

1) the prediction of frost resistance of ceramic products according to the size of pores and their distribution;

2) the prediction for frost resistance of ceramic products according to physical, mechanical and structural properties;

3) the prediction for frost resistance of ceramic products according to structural and deformation properties.

The analysis leads to the following conclusions:

- for prediction of frost resistance of ceramic products during the service life, it is necessary to use methods based on unilateral freezing;

- rapid methods of prediction based on usage of more parameters are much more reliable and better correspond to frost resistance of ceramic products;

- rapid methods of prediction allow to determine quickly frost resistance and to stop the delivery of poor products to construction sites;

- dilatometric methods are more comfortable and therefore more prospective.

Asta Kičaitè. Doctor, Senior Researcher. Dept of Building Materials. Vilnius Gediminas Technical University (VGTU), Saulètekio al. 11, 2040 Vilnius, Lithuania.

Doctor (technical sciences, 1991). Author of 17 publications. Research interests: durability, frost resistance and other properties of building materials and products. 